\title{
Incidence and Screening of Guava (Psidium guajava L.) Varieties against Fruit Borer (Deudorix isocrates F.) in Eastern Gangetic Plains of West Bengal, India
}

\author{
A. Rama Devi* and S. Jha \\ Department of Agricultural Entomology, Bidhan Chandra Krishi Viswavidyalaya, \\ Mohanpur, Nadia-741252, West Bengal, India \\ *Corresponding author
}

\begin{tabular}{|c|c|}
\hline & A B S T R A C T \\
\hline & \multirow{6}{*}{$\begin{array}{l}\text { The seasonal incidence of fruit borer (Deudorix isocrates) infesting guava was carried out } \\
\text { at two locations viz., Horticultural Research Station, Monduri and in guava orchard at } \\
\text { Mohanpur, Nadia, West Bengal during } 2014 \text { and } 2015 \text {. During both years, maximum } \\
\text { incidence of pest (D. isocrates) was observed in the month of August at both locations } \\
\text { with varying weeks of peak periods except during first year (2014) at Mondouri where the } \\
\text { peak incidence was recorded in last week of July. Mean incidence of two locations also } \\
\text { indicated that July end to August end was the peak activity period of the pest. The } \\
\text { correlation studies between fruit borer infestation and weather parameters revealed that } \\
\text { minimum temperature, rainfall and minimum relative humidity resulted in significant } \\
\text { positive influence on fruit borer incidence. Regression analysis also showed that all } \\
\text { weather factors influenced } 61.3 \% \text { variation in the fruit borer incidence. Field screening of } \\
18 \text { guava varieties against the fruit borer during } 2014,2015 \text { and } 2016 \text { revealed minimum } \\
\text { infestation in Dudhkhaja (3.08\%) and Arka Kiran (4.63\%), Kohir Round (6.13\%), } \\
\text { Mohammad Khaja (6.73\%), Baruipur Local ( }(7.61 \%) \text {, HissarSurkha }(8.86 \%) \text { and Lalit } \\
\text { (10.08\%) and maximum infestation in Hissar Safeda(26.4\%), China (24.93\%), Allahabad } \\
\text { Safeda(23.43\%), and Sardar (21.61\%). }\end{array}$} \\
\hline Keywords & \\
\hline $\begin{array}{l}\text { Fruit borer, Guava, } \\
\text { Incidence, Peak } \\
\text { period, Correlation, } \\
\text { Regression. }\end{array}$ & \\
\hline Article Info & \\
\hline $\begin{array}{l}\text { er } 2017 \\
\text { nline: } \\
2017\end{array}$ & \\
\hline & \\
\hline
\end{tabular}

\section{Introduction}

With the establishment of guava orchards in a large area, there has been gradual establishment of pests in the orchards which in turn pose a serious threat to the crop. Several insect-pests viz., fruit flies, bark eating caterpillars, whiteflies, semilooper, fruit borers, stem borers etc. are known to attack guava plants (Butani, 1979). Among different pests infesting guava, lepidopteron fruit borers viz., Deudorix (=Virachola) isocrates Fab. and Dichocrosis punctiferalis
Guen., which were previously considered to be a pests of insignificant importance (Ansari,1945), are presently assuming serious pest status in altering horticultural scenario (Yadav and Pandey, 1995a,b). Both the species are important polyphagous pests and can cause losses up to $24 \%$ in guava (Biswas et al., 1995). D. isocrates is also known as pomegranate butterfly, this is in fact a polyphagous pest attacking a wide range of host plants, including guava, pomegranate, 
anola, apple, ber, citrus, litchi, peach, pear, sapota and tamarind (Atwal, 1976). The crop loss caused by these pests is conventionally minimized by the growers using synthetic pesticides. Indiscriminate use of pesticides either in the form of dust or spray results in residual effect on fruits leading to human health hazards. Exploitation of resistant varieties is one of the most cost-effective and an ecologically harmless means of protecting crops against insect pests, as it is convenient and no special technology to be adopted by the farmer (Helbig, 1997). The incidence of pest is largely affected by the abiotic factors like temperature, relative humidity, rainfall, rainy days, etc. In West Bengal, no such studies have been undertaken to understand the role of weather factors influencing fruit borer incidence in guava.

Furthermore, information on varietal susceptibility under West Bengal conditions was thought to be useful for managing fruit borer menace. Therefore, the present study was carried out to generate information on fruit borer incidence and relative susceptibility of promising varieties of guava in order to aid in taking precise management decisions and their implementation in tackling the fruit borer problems in guava in the eastern Gangetic plains of West Bengal.

\section{Materials and Methods}

The present study on incidence of fruit borer (D. isocrates) was conducted at Horticultural Research Station, Monduri (var. L- 49) and in guava orchard at Mohanpur (var. Baruipur), Nadia, West Bengal during 2014 and 2015. For the study, fifty fruits were randomly drawn from three plants which were treated as a replication. Three such replications had been taken up at both the locations for observing the incidence of $D$. isocrates. The occurrence of borer and percent infestation were determined based on counting the number of healthy and infested fruits at the larval holes at weekly intervals from June to October. The species of $D$. isocrates larva was blackish brown with light yellowish patches and short scattered hairs all over the body. Male appears glossy, bluish violet, female brownish violet with an orange patch on forewings whereas larva of $D$. punctiferalis pale reddish brown with numerous tubercles on body. Adult medium sized bright orange-yellow colour, has numerous black dots on wings. In order to study effect of weather parameters on incidence of fruit borer, data on different meteorological parameters like temperature (maximum and minimum), relative humidity (maximum and minimum), total rainfall $(\mathrm{mm})$ and total sunshine hours in the experimental site were recorded. The average of previous one week data was correlated with the incidence of fruit borer (D. isocrates).

The field experiment on screening of guava varieties against fruit borer (D. isocrates) was laid out in a Randomized Block Design (Gomez and Gomez, 1984); 18 different varieties viz., $\mathrm{V} 1=$ Lalit, $\mathrm{V} 2=$ Allahabad Safeda, V3= Sardar (L-49), V4= Sweta, V5= Philippines, V6 $=$ China (C-3), V7 $=$ Kohir Safeda, V8 $=$ ArkaAmulya, V9 $=$ Hissar Surkha, V10= Safed Jam,V11= Hissar Safeda, V12= Arka Mridula, V13= Arka Kiran, V14= Kohir Round, V15= Mohammad Khaja, V16= Baruipur, V17= DudhKhaja and V18 $=$ Khaja were grown in a plant to plant spacing of $5 \mathrm{~m}$ $\mathrm{x} 5 \mathrm{~m}$ with three replications.

For this, total number of healthy and infested fruits per tree was counted by observing the larval holes in each variety at weekly intervals from July to September of 2014, 2015 and 2016 at Horticulture Research Station, Monduri. The average percent infestation was then worked out to know the varietal reaction to the borer. Each variety constituted one treatment and single tree as one replication. 
Each treatment had three replications. The study area was kept free of insecticidal spray during the period of observation.

\section{Statistical analysis}

The influence of weather parameters on incidence of $D$. isocrates was analyzed by correlation and regression analysis on cumulative basis. Further, for varietal screening studies data obtained was analysed statistically using Randomised Block Design after suitable transformation. The data was analyzed by using statistical software SPSS 20.0 .

\section{Results and discussion}

\section{Fruit borer on guava}

Two fruit borers, Deudorix isocrates and Dichocrosis punctiferalis were identified from guava, the damage of $D$. punctiferalis was observed to be of very negligible extent during the period of study and so that was not taken under the study. The caterpillars of $D$. isocrates made holes mostly at the stalk end to middle of the fruit. It was further observed that, in general pest preferred to attack all stages of fruits; they feed on the seeds and flesh inside too. The small green fruits when attacked could not ripe and if cut open black mass could be seen inside that might be due to secondary infections. When attacked matured fruits were split open, seeds were found to be like a dried mass. It was also noted that unlike other borer ( $D$. punctiferalis), the attack of $D$. isocrates could be visually identified through faecal matter plugged on the entry holes. The larvae feeding within could have also come out and attack new fruits. The infested and bored fruits did not develop and slowly dried up. Beside this, the pest was also found to attack flower buds which adversely caused reduction in the reproductive growth with a follow up of yield loss.

\section{Incidence at Mondouri during 2014 and} 2015

The result on incidence of fruit borer on guava during 2014 at Mondouri presented in figure 1 indicated that, the borer could be first recorded in the field during second week of June and remained on the crop for nineteen weeks and it took six weeks to reach peak and the declining period was for thirteen weeks. The infestation of the pest started during second week of June ( $24^{\text {th }}$ standard week-SW) with $3.67 \%$ damage load. During preceding one week period of the initial infestation, $\mathrm{T}$ max ranged from 29 to $34.7^{\circ} \mathrm{C}$ (average $31.89^{\circ} \mathrm{C}$ ), Tmin ranged from 24.5 to $27.8^{\circ} \mathrm{C}$ (average $26.50^{\circ} \mathrm{C}$ ), $\mathrm{RH}$ max varied from 73 to $84 \%$ (average $89.14 \%$ ), $\mathrm{RH}$ min ranged from 65 to $72 \%$ (average $68.71 \%$ ) and rainfall from 0 to $22.8 \mathrm{~mm}$. Then the pest incidence increased more rapidly to reach its peak during last week of July i.e., $30^{\text {th }} \mathrm{SW}$ $(24.67 \%)$. During preceding one week period of the peak stage, $\mathrm{T}$ max ranged from 31.2 to $33.5^{\circ} \mathrm{C}$ (average $32.29^{\circ} \mathrm{C}$ ), $\mathrm{T}$ min ranged from 24.9 to 27 (average $26.21^{\circ} \mathrm{C}$ ), $\mathrm{RH}$ max ranged from 91 to $98 \%$ (average $94.86 \%$ ), $\mathrm{RH}$ min ranged from 74 to100 \% (average 87.71\%) and rainfall ranged from 0 to $43.6 \mathrm{~mm}$. However, infestation remained almost static during the following week i.e., first week of August ( $31^{\text {st }} \mathrm{SW}$ ) with $23.67 \%$ infestation and then started declining slowly from second week of August to first week of September i.e., $32^{\text {nd }}$ to $36^{\text {th }} \mathrm{SW}$. Thereafter, infestation found to be increased in second week of September $\left(37^{\text {th }} \mathrm{SW}\right)$ with $16.3 \%$ damage. Then its incidence started to decrease till last week of October.

In the second year of study at Mondouri during 2015, presented in figure 2 indicated that pest was found in the field for nineteen weeks. It took eight weeks to grow to reach its peak and the declining phase was for eleven weeks. There was no infestation during 
second week of June $\left(24^{\text {th }} \mathrm{SW}\right)$. The infestation of borer (4.67\%) started appearing in third week of June i.e., $25^{\text {th }} \mathrm{SW}$, during preceding one week period of the initial stage, $\mathrm{T}$ max ranged from 31.4 to $35.5^{\circ} \mathrm{C}$ (average $34.10^{\circ} \mathrm{C}$ ), $\mathrm{T}$ min ranged from 20.00 to $26.00^{\circ} \mathrm{C}$ (average $23.56^{\circ} \mathrm{C}$ ), $\mathrm{RH}$ max ranged from 89 to $92 \%$ (average $90.71 \%$ ), $\mathrm{RH}$ min ranged from 61 to $81 \%$ (average $69.57 \%$ ), and rainfall ranged from 0 to $8.2 \mathrm{~mm}$. Then, infestation started increasing rapidly to reach its peak during third week of August $\left(33^{\text {rd }}\right.$ SW) with $28.33 \%$ infestation. During preceding one week period of the peak stage, $\mathrm{T}$ max ranged from 34.4 to $35.8^{\circ} \mathrm{C}$ (average $34.71^{\circ} \mathrm{C}$ ), $\mathrm{T}$ min ranged from 24.8 to $26.5^{\circ} \mathrm{C}$ (average $26.00^{\circ} \mathrm{C}$ ), RH max ranged from 87 to $97 \%$ (average $94.34 \%$ ), $\mathrm{RH}$ min ranged from 70 to $89 \%$ (average $80.57 \%$ ) and rainfall varied from 2.2 to $64.5 \mathrm{~mm}$. Then, the infestation started falling slowly from fourth week of August i.e., 34 ${ }^{\text {th }}$ SW (27.67\%) onwards and this trend continued up to last week of October $\left(43^{\text {rd }} \mathrm{SW}\right)$ with $1.67 \%$ infestation.

\section{Incidence at Mohanpur during 2014 and 2015}

The result regarding the incidence of fruit borer on guava during 2014 at Mohanpur presented in figure 3 indicated that, the infestation was found in the field for eighteen weeks. It took six weeks to grow to reach its peak and the declining phase was for twelve weeks. There was no infestation during second week of June $\left(24^{\text {th }} \mathrm{SW}\right)$.However, when borer infestation (1.33\%) started appearing i.e., $25^{\text {th }} \mathrm{SW}$, preceding one weeks average $\mathrm{T}$ max and $\mathrm{T}$ min were $33.80^{\circ} \mathrm{C}$ and $26.93^{\circ} \mathrm{C}$, average $\mathrm{RH}$ max and $\mathrm{RH}$ min were 92.29 and $81.57 \%$ with rainfall of $12.91 \mathrm{~mm}$. Later on the increasing trend of borer infestation continued and attained peak $(15.33 \%)$ during first week of August $\left(31^{\mathrm{st}} \mathrm{SW}\right)$. During preceding one week period of the peak stage, the T max ranged from 29.4 to $35.5^{\circ} \mathrm{C}$ (average $33.66^{\circ} \mathrm{C}$ ), $\mathrm{T}$ min ranged from 24.7 to 28.5 (average $27.23^{\circ} \mathrm{C}$ ), $\mathrm{RH}$ max ranged from 93.24 to $100 \%$ (average $97.29 \%$ ), $\mathrm{RH}$ min ranged from 73.12 to $100 \%$ (average $85.86 \%$ ) and rainfall varied from 0 to $31.5 \mathrm{~mm}$. The borer infestation during first and second week of August remained almost static $\left(31^{\text {st }}\right.$ and $\left.32^{\text {nd }} \mathrm{SW}\right)$. Then the infestation started declining from third week of August to first week of September i.e., $33^{\text {rd }}$ to $36^{\text {th }} \mathrm{SW}$. The infestation ranged between 6.67 to $12.00 \%$ during these weeks. But again in second week of September $\left(37^{\text {th }} \mathrm{SW}\right)$ it increased slightly with $7.33 \%$ infestation and thereafter it declined till last week of October.

In the second year of study at Mohanpur (2015), from figure 4 , it is clear that the infestation was found in the field for eighteen weeks. It took six weeks to reach its peak and the declining phase was for eleven weeks. Initiation of infestation of fruit borers on guava started appearing in fourth week of June $\left(26^{\text {th }} \mathrm{SW}\right)$ with $3.67 \%$ infestation, when the average $\mathrm{T}$ max, $\mathrm{T}$ min, $\mathrm{RH} \max , \mathrm{RH}$ min and rainfall preceding one week of this were $29.89^{\circ} \mathrm{C}, 25.24^{\circ} \mathrm{C}, 97.14 \%, 72.14 \%$ and 12.36 $\mathrm{mm}$, respectively. The infestation was highest during second week of August i.e., $32^{\text {nd }} \mathrm{SW}$ with $21.33 \%$ infestation, where average $\mathrm{T}$ $\max \left(32.93^{\circ} \mathrm{C}\right), \mathrm{T} \min \left(25.03^{\circ} \mathrm{C}\right), \mathrm{RH} \max$ $(98.65 \%)$, RH $\min (92.23 \%)$ with rainfall of $25.81 \mathrm{~mm}$ was recorded before this week. However, the infestation started declining from third week of August to last week of October $\left(33^{\text {rd }}\right.$ to $\left.43^{\text {rd }} \mathrm{SW}\right)$. The infestation ranged between 2.67 to $18.67 \%$ during these weeks.

While comparing the fruit borer incidence at Mondouri and Mohanpur, during first year (2014), in the guava orchards, it had been found that incidence of fruit borer ranged from 2.67 to $24.67 \%$ and 0.00 to $15.33 \%$, respectively during June to October. Highest 
incidence (24.67\%) was recorded in last week of July $\left(30^{\text {th }} \mathrm{SW}\right)$ at Mondouri while the peak incidence at Mohanpur observed in first week of August $\left(31^{\mathrm{st}} \mathrm{SW}\right)$.During second year (2015), incidence of fruit borer ranged from 0.00 to $28.33 \%$ and 0.00 to $21.33 \%$ at Mondouri and Mohanpur, respectively. Infestation appeared a week early i.e., in third week of June $\left(25^{\text {th }} \mathrm{SW}\right)$ at Mondouri (4.67\%) compared to Mohanpur (3.67\%) which started in fourth week of June $\left(26^{\text {th }} \mathrm{SW}\right)$. The infestation was highest in third week of August $\left(33^{\text {rd }} \mathrm{SW}\right)$ with $28.33 \%$ infestation at Mondouri while at Mohanpur peak infestation of 21.33\% during second week of August $\left(32^{\text {nd }} \mathrm{SW}\right)$ was noted.

Average incidence of the pest during both years 2014 and 2015 was higher at Mondouri (13.05 and $15.30 \%)$ as compared to that at Mohanpur (6.17 and 10.02\%). This difference, possibly, was due to varietal difference. In Mohanpur, the variety cultivated was Baruipur Local which in our study was found to be low in attack, whereas, at mondouri variety Sardar (L-49) had been taken up for study where fruit borer attack was at more level.

Fig.1 Incidence of D. isocrates on guava along with weather factors at Mondouri during 2014

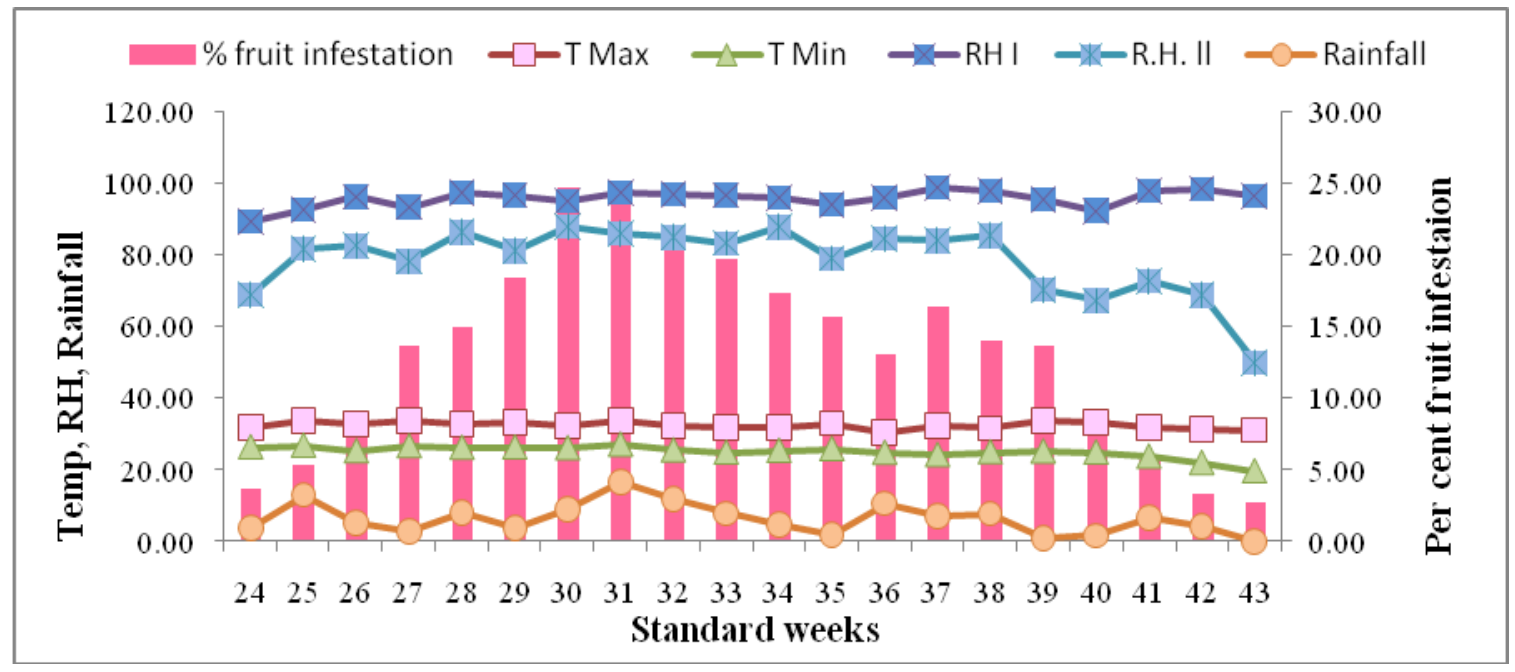

Fig.2 Incidence of $D$. isocrates on guava along with weather factors at Mondouri during 2015

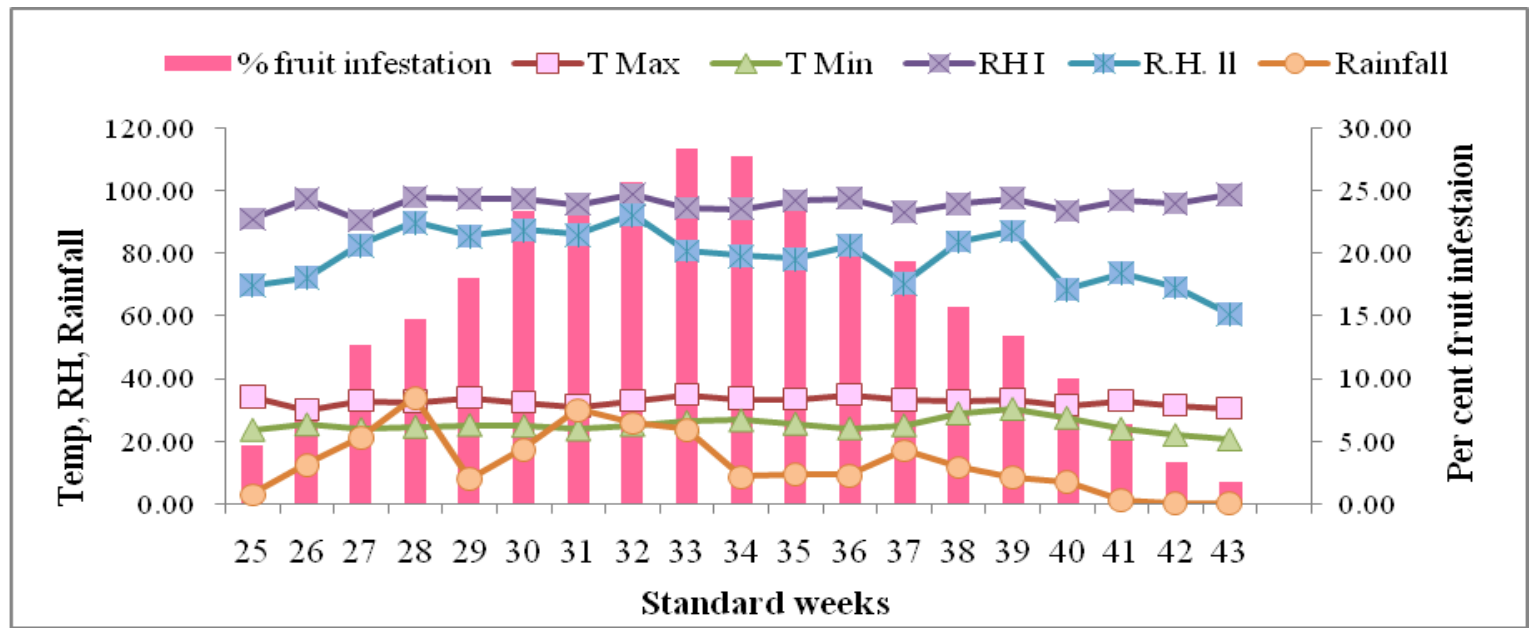


Fig.3 Incidence of D. isocrates on guava along with weather factors at Mohanpur during 2014

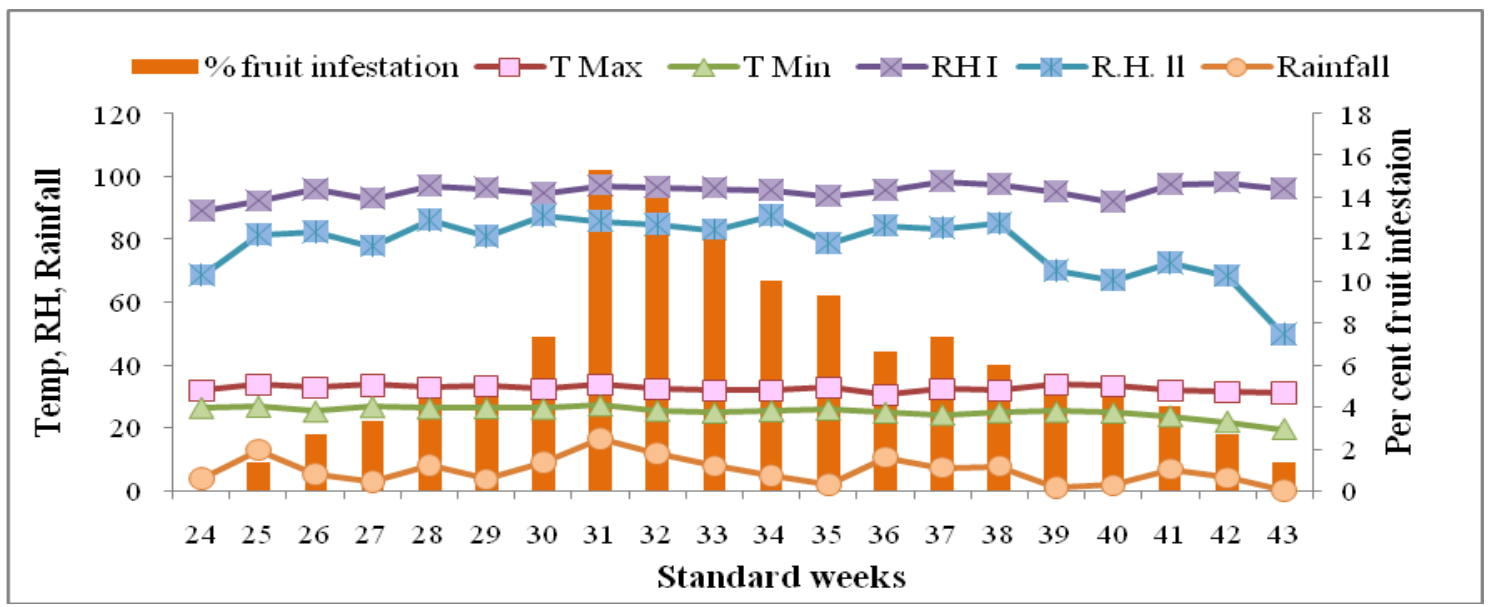

Fig.4 Incidence of $D$. isocrates on guava along with weather factors at Mohanpur during 2015

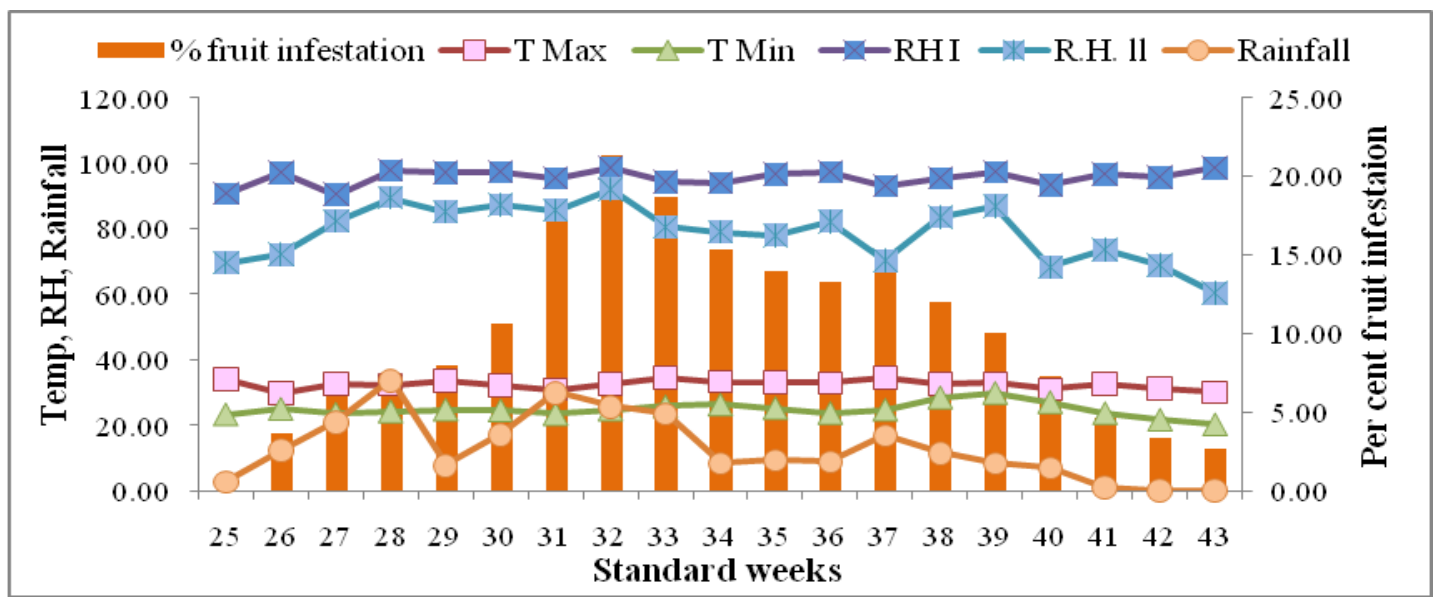

Fig.5 Mean per cent fruit infestation by fruit borer (D. isocrates) in different guava varieties during 2014, 2015 and 2016

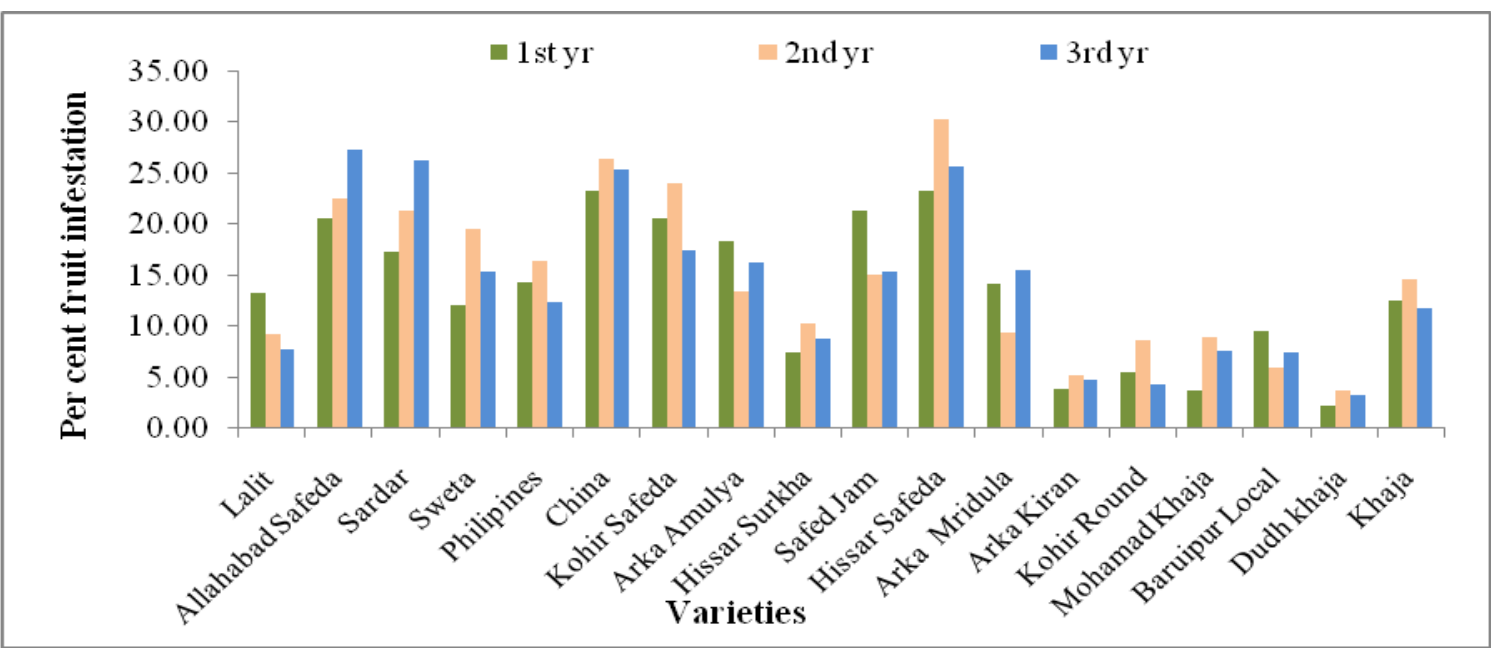


Table.1 Simple correlation between fruit borer incidence and weather parameters

\begin{tabular}{|c|c|c|c|c|c|}
\hline \multirow{2}{*}{$\begin{array}{c}\text { Cumulative } \\
(\mathbf{2 0 1 4 + 2 0 1 5 )}\end{array}$} & \multicolumn{2}{|c|}{ Temperature $\left({ }^{\circ} \mathbf{C}\right)$} & \multicolumn{2}{|c|}{ Relative Humidity (\%) } & \multirow{2}{*}{ Rainfall (mm) } \\
\cline { 2 - 5 } Max. & Min. & Max. & Min. & \\
\hline Mondouri & 0.126 & $0.278^{*}$ & 0.330 & $0.669^{* *}$ & $0.330^{*}$ \\
\hline Mohanpur & 0.178 & $0.295^{*}$ & 0.249 & $0.528^{* *}$ & $0.421^{* *}$ \\
\hline
\end{tabular}

$\mathrm{Y}=-136.390+1.242(\mathrm{X} 1)-0.076(\mathrm{X} 2) * *+0.811(\mathrm{X} 3)+0.412(\mathrm{X} 4) *+0.329(\mathrm{X} 5) *\left(\mathrm{R}^{2}=0.613\right)$

Where, Where $\mathrm{Y}=\%$ fruit infested $\mathrm{X} 1=$ Temperature maximum $\left({ }^{\circ} \mathrm{C}\right), \mathrm{X} 2=$ Temperature minimum $\left({ }^{\circ} \mathrm{C}\right), \mathrm{X} 3=$ Relative humidity maximum (\%), X4= Relative humidity minimum (\%), X5= Rainfall (mm), $\mathrm{R}^{2}=$ Coefficient of Determination, *Significant at $5 \%, * *$ Significant at $1 \%$

Table.2 Categorization of guava varieties on the basis of fruit infestation by fruit borer

\begin{tabular}{|c|c|c|l|}
\hline Sl.no & Category & Fruit infestation (\%) & \multicolumn{1}{|c|}{ Varieties } \\
\hline 1. & Very low & $0-5$ & Dudhkhaja, Arka Kiran \\
\hline 2 & Low & $6-10$ & Lalit, HissarSurkha, Baruipur Local, Mohamad Khaja and Kohir Round \\
\hline 3 & Moderate & $11-15$ & Khaja, ArkaMridula, Philipines, Sweta and ArkaAmulya \\
\hline 4 & Serious & $>16$ & Safed Jam, KohirSafeda, HissarSafeda, China, Allahabad Safeda and Sardar \\
\hline
\end{tabular}

Based on mean of 2014, 2015 and 2016

Table.3 Screening of guava varieties against fruit borer (D. isocrates)

(Pooled data of 2014, 2015 and 2016)

\begin{tabular}{|c|l|c|c|c|c|}
\hline \multirow{2}{*}{ Sr.no } & \multirow{2}{*}{ Varieties } & \multicolumn{2}{|c|}{ Per cent fruit infestation } & \multirow{2}{*}{ Mean } \\
\cline { 2 - 5 } 1 & Lalit & July & August & September & \\
\hline 2 & Allahabad Safeda & $22.53(15.65(27.79)$ & $12.11(20.04)$ & $10.61(18.69)$ & 10.08 \\
\hline 3 & Sardar & $24.63(29.59)$ & $22.1(27.92)$ & $20.37(26.57)$ & 23.43 \\
\hline 4 & Sweta & $12.05(20.53)$ & $19.57(26.08)$ & $15.43(24.88)$ & 21.61 \\
\hline 5 & Philippines & $11.28(19.32)$ & $18.08(25.07)$ & $13.63(21.54)$ & 15.68 \\
\hline 6 & China & $27.62(31.56)$ & $27.12(31.29)$ & $20.05(26.49)$ & 14.33 \\
\hline 7 & Kohir Safeda & $24.21(29.27)$ & $22.97(28.40)$ & $14.85(22.49)$ & 20.68 \\
\hline 8 & ArkaAmulya & $18.95(25.56)$ & $16.06(22.05)$ & $12.85(20.82)$ & 15.96 \\
\hline 9 & HissarSurkha & $6.26(13.34)$ & $10.74(18.81)$ & $9.58(16.84)$ & 8.86 \\
\hline 10 & Safed Jam & $21.24(27.38)$ & $15.09(22.82)$ & $15.38(23.15)$ & 17.24 \\
\hline 11 & Hissar Safeda & $25.50(30.20)$ & $31.95(34.32)$ & $21.75(27.63)$ & 26.40 \\
\hline 12 & Arka Mridula & $11.18(18.16)$ & $16.54(23.79)$ & $11.25(18.35)$ & 12.99 \\
\hline 13 & Arka Kiran & $5.04(11.27)$ & $5.83(12.93)$ & $3.02(7.76)$ & 4.63 \\
\hline 14 & Kohir Round & $6.99(14.79)$ & $7.74(14.95)$ & $3.66(8.63)$ & 6.13 \\
\hline 15 & MohamadKhaja & $3.68(10.06)$ & $8.96(16.96)$ & $7.56(15.84)$ & 6.73 \\
\hline 16 & Baruipur Local & $8.12(15.06)$ & $10.35(18.42)$ & $4.37(11.24)$ & 7.61 \\
\hline 17 & Dudhkhaja & $2.23(6.95)$ & $3.77(10.68)$ & $3.24(10.20)$ & 3.08 \\
\hline 18 & Khaja & $15.60(23.14)$ & $14.01(21.74)$ & $9.24(17.48)$ & 12.95 \\
\hline S.Em \pm ( $)$ & 2.483 & 2.852 & 3.076 & \\
\hline CD (P=0.05) & 7.192 & 8.164 & 8.674 & \\
\hline
\end{tabular}

Figures in parentheses are arc sin transformed values 
The present findings are in agreement with those of Kaul and Kesar (2003) who reported that peak incidence of $D$. isocrates and $D$. punctiferalis (=Conogethes punctiferalis), was observed in the $32^{\text {nd }}$ standard week at Udheywalla, while at Raya the peak incidence (9\%) was recorded in $33^{\text {rd }}$ standard week. Results of Haseeb and Sharma (2007) on the incidence of $D$. isocrates observed that it was at its peak on cv. L-49 in the month of August in rainy crop are also in support of present findings. The present finding are in close accordance with those of Biswas et al., (1995) who referred that infestation by fruit borer began at the marble stage of guava and the peak infestation was recorded in mid-August to September in varieties 'Kazipiara', 'Kanchannagar', 'Mukundapuri' and 'Swarupkathi'. Infestation by $D$. isocrates began in last week of June ${ }^{[13]}$. Yadav and Pandey (1995a). Data presented here is more or less similar with the findings of Sunita (2012) who observed that, anar butterfly (V.isocrates) was found the highest $(35.600$ per unit) in 3rd week of September and it was followed by 32.219 in the 3rd week of August, 28.285 in the 2nd week of September and 27.180 in the 4th week of August.

\section{Role of weather factors in influencing fruit borer incidence in guava orchards}

The results of simple correlation worked out between mean fruit borer infestation and weather parameters on cumulative basis at Mondouri presented in Table 1, observed significant positive correlation with $\mathrm{T}$ min (0.278), $\mathrm{RH} \min (\mathrm{r}=0.669)$ and rainfall $(\mathrm{r}=$ 0.330 ) indicating the high impact on the incidence of fruit borer. However, the response of $\mathrm{T} \min (\mathrm{r}=0.295), \mathrm{RH} \min (\mathrm{r}=$ $0.528)$ and rainfall $(\mathrm{r}=0.421)$ exerted positive and significant correlation values on cumulative basis at Mohanpur also. The results corroborate with the findings of Yadav and Pandey (1995b) who also found that correlation between level of pest infestation and temperature, relative humidity and rainfall was positive and significant. The abiotic factors like temperature, $\mathrm{RH}$ min and rainfall influenced the fruit borer occurrence in guava Kaul and Kesar (2003).

Regression analysis of average fruit borer infestation of both locations Mohanpur and Mondouri with weather factors on cumulative basis, the coefficient of determination $\left(\mathrm{R}^{2}\right)$ value was 0.613 indicating that when all weather factors are computed together caused as much as $61.3 \%$ variation in the larval population of fruit borer can take place with the variation in weather factors. This results can be supported by Kaul and Kesar (2003) who showed that the abiotic factors like maximum temperature, minimum temperature, relative humidity (morning and evening) and rainfall, contributed up to $63.2 \%$ $\left(\mathrm{R}^{2}=0.632\right)$ of the fruit borer infestation in guava.

\section{Screening of different guava varieties against fruit borer}

Eighteen guava varieties were screened for their relative susceptibility to fruit borer, and the data of three experimental years (2014, 2015 and 2016) were pooled and presented in Table 3 and figure 5 and categorisation of varieties was done based on the scale provided in the Table 2, as suggested by Sandhu et al., (1979). It is clear that two varieties, Dudhkhaja (3.08\%) and Arka Kiran $(4.63 \%)$ were categorised as very low infested while Kohir Round, Mohammad Khaja, Baruipur Local, Hissar Surkha and Lalit were categorised as low infested having infestations of $6.13,6.73,7.61,8.86$ and $10.08 \%$, respectively. Moderately damaged varieties include Khaja (12.95\%), Arka Mridula (12.99\%), Philipines (14.33\%), Sweta (15.68\%) and Arka Amulya (15.96\%). Safed Jam and Kohir Safeda were categorised 
as seriously damaged as fruit borer infestation was about 17.24 and $20.68 \%$, respectively. Very seriously infested varieties in the present study includes Sardar (21.61\%), Allahabad Safeda (23.43\%), China (24.93\%) and Hissar Safeda $(26.4 \%)$.

It can be noticed that the peak periods of infestation of fruit borer on the guava crop was July and August months in most of the varieties. After appearance, the infestation of the pest increased continuously up to the month of August and then decreased in September in most of the cases.

The present results are in support of (Anonymous, 2003) who observed average fruit loss in weight by Virachola isocrates varied from 11.09 to 13.88 and 20.69 to 21.38 per cent in cvs L-49 and Allahabad Safeda in rainy season, while it was 20.69 to 21.38 per cent in L-49 in winter season. Other authors Biswas et al., (1995) screened 4 guava varieties against $D$. isocrates on guava, the highest infestation occurred in cv. Kazipiara resulting in $24.2 \%$ fruit damage and $22.7 \%$ weight loss, and the lowest in cv. Swarupkathi with $7.8 \%$ fruit damage and $6.8 \%$ weight loss. Severe infestation of two borers, namely $D$. isocrates and D. punctiferalis (=Conogethes punctiferalis), found in guava orchards and among the varieties screened, Allahabad Safeda was the least susceptible with $9.50 \%$ fruit infestation at maturity, whereas Red flesh was the most susceptible with $14.30 \%$ fruit infestation. The order of susceptibility was Red Flesh > Hybrid No. 1 > Hybrid No. 2 $>$ Lucknow-49 > Allahabad Safeda (Gupta and Arora, 2001).

The infestation of fruit borer (D. isocrates) was seen in the field from $2^{\text {nd }}$ or $3^{\text {rd }}$ week of June and maximum incidence of it could be observed during end July to $2^{\text {nd }}$ or $3^{\text {rd }}$ week of August which was the peak activity period of the pest from both the study years. Therefore, the initiation of control measures should be decided accordingly on the basis of their prevalence. Fruit borer incidence was positive and significantly correlated with minimum temperature, $\mathrm{RH}$ minimum and rainfall which can be used for decision making. Out of 18 varieties screened for their relative susceptibility to fruit borer during 2014, 2015 and 2016, it revealed low infestation of the fruit borer in Dudhkhaja (3.08\%) and Arka Kiran $(4.63 \%)$ while high infested varieties includes Sardar (21.61\%), Allahabad Safeda (23.43\%), China (24.93\%) and Hissar Safeda $(26.4 \%)$. Thus, areas where there is problem of this pest those varieties can be kept in mind while planting to protect from fruit borer.

\section{Acknowledgement}

Authors are highly thankful to Department of Fruit and orchard Management, and the Director of Research, Bidhan Chandra Krishi Viswavidyalaya, Mohanpur, for the necessary facilities and encouragement during course of present investigation and also thankful to Department of Agricultural Meteorology \& Physics, BCKV for providing weather data.

\section{References}

Anonymous. Annual Report 2002-2003, Central Institute of Sub-tropical Horticulture, Lucknow, Uttar Pradesh, India. 2003.

Ansari, M. A., 1945. Dichocrosis punctiferalis Guen as a pest of Guava. Indian Journal of Entomology. 7: 241.

Atwal, A. S., 1976. Agricultural Pest of India and South-East Asia. Kalyani Publishers, Ludhiana. Pp.189-190.

Biswas, G. C., Ahmad, M., Karim, M. A. and Mian, M. Y. 1995. Incidence of fruit borer (Virachola isocrates F.) on guava at Khagrachari Hill District. Bangladesh Journal of Entomology. 5(1/2): 33-39

Butani, D. K., 1979. Insects and fruits, Pub: 
Periodical Expert Book Agency, Delhi, 55-68pp.

Gomez K.A., Gomez A.A. Statistical procedures for agricultural research, $2^{\text {nd }}$ edition. John Wiley and Sons, New York. 1984; P.680.

Gupta, R. K., and Arora, R. K. 2001. Lepidopteran fruit borers on guava in Jammu. Insect Environment. 7(2): 8384.

Haseeb, M., and Sharma, S. 2007. Studies on incidence and crop losses by fruit borer Deudorix isocrates (Lepidoptera: Lycaenidae) on guava. Acta Horticulturae. (735): 489-492.

Helbig, J., 1997. Host plant resistance to storage insect pests. In: Anonymous (ed.) Integrating biological control and host plant resistance. Proceedings of CTA/IAR/IIBC Seminar. Addis-Ababa, Ethiopia, 1995, pp 66-72.

Kaul, V., and Kesar, Y. K. 2003. Incidence and management of lepidopteran fruit borers of guava (Psidium guajava L.) in Jammu, India. Journal of Asia Pacific Entomology. 6(2): 201-205.

Sandhu, G. S., Deol, I. S. and Sohi, A. S. 1979. Incidence of fruit boring insects in guava cultivars. Punjab Horticultural Journal. 19: 171-173.

Sunita, S., 2012. Intensity of anar butterfly Virachola isocrates (Fabr.) with period and crop means. Recent Research in Science and Technology. 4(9): 14-15.

Yadav, L. B., and Pandey, V. 1995a. Incidence of Pomegranate butterfly Virachola isocrates in guava orchard and guava based cropping system. Bulletin of Entomology. 36: 84-91.

Yadav, L. B., and Pandey, V. 1995b. Guava fruit infestation by pomegranate butterfly Virachola isocrates in relation to weather factors. Bulletin of Entomology. 36(1/2): 113-116.

\section{How to cite this article:}

Rama Devi, A., and Jha, S. 2017. Incidence and Screening of Guava (Psidium guajava L.) Varieties against Fruit Borer (Deudorix isocrates F.) in Eastern Gangetic Plains of West Bengal, India. Int.J.Curr.Microbiol.App.Sci. 6(10): 1689-1698. doi: https://doi.org/10.20546/ijcmas.2017.610.204 